\title{
Taql B1/B2 and -629A/C cholesteryl ester transfer protein (CETP) gene polymorphisms and their association with CETP activity and high-density lipoprotein cholesterol levels in a Tehranian population. Part of the Tehran Lipid and Glucose Study (TLGS)
}

\author{
Maryam S Daneshpour, Mehdi Hedayati and Fereidoun Azizi \\ Obesity Research Center, Research Institute for Endocrine Sciences, \\ Shaheed Beheshti University of Medical Sciences, Tehran, I.R. Iran
}

\begin{abstract}
We examined the cholesteryl ester transfer protein (CETP) gene Taql intron 1 B1/B2 polymorphism and the -629A/C CETP promoter polymorphism in respect to high-density lipoprotein cholesterol (HDL-C) in a healthy Iranian population taken from the Tehran Lipid and Glucose Study (TLGS). The relationship between CETP activity and HDL-C level was also determined along with body mass index, blood pressure and tobacco smoking status. PCR-RFLP used to amplify a segment of the CETP intron $1 \mathrm{Taql}$ (B2/B1) polymorphism from 1021 individuals and we selected 345 individuals from the lowest, middle and highest HDL-C deciles and investigated the -629A/C polymorphism. We also evaluated the CETP activity of 103 of these individuals, each with at least one homozygous allele. The presence of the Taql $B 2$ and $-629 \mathrm{~A} / \mathrm{C}$ A alleles were significantly associated with increased HDL-C levels (B2B2 $=1.19 \pm 0.31$ $\mathrm{mmolL}^{-1}$ vs. B1B1 $=1.01 \pm 0.2 \mathrm{mmol} \mathrm{L}^{-1}$ for $\mathrm{p}<0.001 ; \mathrm{AA}=1.15 \pm 0.41 \mathrm{mmol} \mathrm{L}^{-1} \mathrm{vs} . \mathrm{CC}=0.95 \pm 0.28 \mathrm{mmol} \mathrm{L}^{-1}$ for $\mathrm{p}<0.001)$ and decreased the CETP activity (B1B1 $=67.8 \pm 8.9 \mathrm{pmol} \mathrm{L}^{-1} v \mathrm{~s}$. B2B2 $=62.6 \pm 9.6 \mathrm{pmol}^{-1}$ for $\mathrm{p}<0.01$; $\mathrm{CC}=68.6 \pm 8.4 \mathrm{pmol} \mathrm{L} \mathrm{L}^{-1}$ vs. $\mathrm{AA}=62.7 \pm 9.7 \mathrm{pmol} \mathrm{L}^{-1}$ for $\mathrm{p}<0.002$ ). The frequencies were 0.382 for the Taql $\mathrm{B} 2$ allele and 0.462 for the $-629 \mathrm{~A} / \mathrm{C}$ A allele, with linkage disequilibrium analysis giving $\mathrm{D}=0.0965$ and $\mathrm{D}^{\prime}=0.4695$. We demonstrated that the Taql B1 and B2 alleles and the -629A/C A and C alleles were in linkage disequilibrium in our population and that there was a significant association between the B2 and A alleles and high HDL-C levels and low CETP activity. Linkage disequilibrium between the Taql A and B2 alleles also detected.
\end{abstract}

Key words: cholesteryl ester transfer protein (CETP), Hardy-Weinberg equilibrium, linkage disequilibrium, polymorphisms.

Received: August 8, 2006; Accepted: April 26, 2007.

\section{Introduction}

Various authors (Gordon et al., 1977; Assmann et al., 1986; Miller et al., 1997) have reported the strong inverse correlation between plasma high-density lipoprotein cholesterol (HDL-C) and the incidence of coronary artery disease (CAD) and are the reasons for the widespread interest in the environmental and genetic factors regulating plasma HDL-C levels. It known that HDL-C plays a central role in the transport of cholesterol from peripheral tissues, including coronary arteries, to the liver in a process of reverse cholesterol transport, which is believed to explain the major anti-atherogenic action of this lipoprotein fraction (Golmest et al., 1972; Bruse et al., 1995; Fielding et al., 1995). Free cholesterol is esterified with the HDL-C fraction during transport and subsequently transferred by the choles-

Send correspondence to Fereidoun Azizi. Shaheed Beheshti University of Medical Sciences, PO Box 19195-4763 Tehran, I.R. Iran. E-mail: azizi@erc.ac.ir. teryl ester transfer protein (CETP) to triglyceride-rich lipoproteins (Tall et al., 1993). Variations in the excess cholesterol removal efficiency from peripheral tissues or the cholesteryl ester transfer between lipoprotein classes could be of vital importance in atherogenesis.

Human CETP is a plasma glycoprotein $\left(M_{\mathrm{r}}=74000\right)$ that mediates the transfer of cholesteryl esters, phospholipids and triglycerides between plasma lipoproteins (Yen et al., 1989). The CETP gene spans $\sim 25000$ base pairs and is composed of 16 exons (Agellom et al., 1990). Gene defects that result in a complete loss of CETP activity are one cause of hyper-alpha-lipoproteinemia (Brown et al., 1989; Inazo et al., 1990), which was originally described as being associated with an increased lifespan (Inazo et al., 1990). However, Hirano et al. (1995) recently reported atherosclerotic disease in heterozygotes for CETP deficiency with low hepatic lipase activities. The most studied restriction fragment length polymorphism (RFLP) of the CETP gene 
is the silent base change in the $277^{\text {th }}$ nucleotide of the first CETP intron, which has been investigated with the TaqI restriction enzyme (Drayana et al., 1987). The B2 allele, coding for the absence of the TaqI restriction site, at this polymorphic site has been associated with normolipemic subjects with increased HDL-C cholesterol (HDL-C) levels and decreased CETP activity and levels (Kondo et al., 1989; Freeman et al., 1994). A polymorphism (A-629C) has also been described in the CETP promoter region at -629 , the A allele being associated with $25 \%$ lower in vitro transcription activity and lower in vivo plasma CETP mass but increased in vivo HDL cholesterol levels (Dachet et al., 2000). The A-629C polymorphism has appeared in linkage disequilibrium with the CETP TaqI polymorphism in nondiabetic European Caucasian males with cardiovascular disease (Corbex et al., 2000; Dachet et al., 2000).

It has been suggested that these associations may be population related (Tenkanen et al., 1991; Mitchell et al., 1994) and highly influenced by environmental factors, such as tobacco smoking (Kauma et al., 1996). Also, Kuivenhoven et al. (1998) showed interactions between the TaqI genotype and the progression of coronary heart disease (CHD) after therapy. These observations could be of significance because low plasma HDL-C levels are associated with an increase in the risk of coronary artery disease. Moreover, clinical evidence suggests that an increase of $1 \%$ in the plasma HDL-C levels is associated with a reduction in cardiovascular morbidity and mortality of $2 \%$ to $3 \%$. Therefore, CETP could have a relevant role in atherogenesis through its effects on HDL-C metabolism.

The Tehran Lipid and Glucose Study (TLGS, see Internet Resources, below) was designed to determine the risk factors for major non-communicable disorders, including atherosclerosis, occurring in the urban population of the
Iranian capital city of Tehran. The TLGS is an ongoing study involving about 15,005 participants of all ages and has the broad aim of developing population-based measures to alter the life-style of the Tehranian population and prevent the rising trend of diabetes mellitus, dietary disorders and dyslipidemia, and to this end (Azizi et al., 2000; Azizi et al., 2003a, b).

The aim of the study described in this paper was to investigate the role of the frequently occurring TaqI B2/B1 polymorphism in interon 1 of the CETP gene promoter and the A-629C CETP gene polymorphism and CETP enzyme activity on the HDL-C levels of some TLGS participants.

\section{Materials and Methods}

\section{Study outline}

From March to September 2003 we examined 1021, apparently healthy, participants (Table 1) enrolled in the TLGS for HDL-C levels and the TaqI B2/B1 polymorphism in interon 1 of the CETP gene promoter. From this sample, we selected a subset of 335 individuals, which we grouped into low, medium and high HDL-C categories and measured the A-629C CETP gene polymorphism and then selected a subgroup of 103 individuals for the measurement of phenotypic CETP activity. This study was approved by the Medical Ethics Committee of the endocrine research center and informed patient consent was obtained.

\section{The 1021 individual selected from the TLGS}

We measured the height, body mass, body mass index (BMI, the body mass in $\mathrm{kg}$ divided by the square of the individual's height in meters) and blood pressure of each of the 1021 individuals selected from the TLGS. Each individual fasted for $12 \mathrm{~h}$ and then whole blood samples were col-

Table 1 - Demographic, genotypic and biochemical parameters of some participants ( $\mathrm{n}=1021)$ in the Tehran Lipid and Glucose Study (TLGS) according to sex. Values are, as appropriate, means \pm standard deviation or percentages.

\begin{tabular}{|c|c|c|c|}
\hline Parameters & $\begin{array}{c}\text { Men } \\
(\mathrm{n}=467)\end{array}$ & $\begin{array}{l}\text { Women } \\
(\mathrm{n}=554)\end{array}$ & p-value \\
\hline Age (years) & $35.2 \pm 18.0$ & $35.3 \pm 18.3$ & 0.931 \\
\hline Body mass index (BMI, $\left.\mathrm{kg} \mathrm{m}^{-2}\right)^{*}$ & $24.5 \pm 4.87$ & $25.7 \pm 5.7$ & 0.001 \\
\hline Systolic blood pressure $(\mathrm{mm} \mathrm{Hg})^{\dagger}$ & $114 \pm 16$ & $109 \pm 19$ & 0.001 \\
\hline Diastolic blood pressure (mm Hg) & $73 \pm 11$ & $72 \pm 10$ & 0.077 \\
\hline Total cholesterol (TC, $\left.\mathrm{mmol} \mathrm{L}^{-1}\right)$ & $4.45 \pm 1.01$ & $4.61 \pm 1.06$ & 0.012 \\
\hline Low-density lipoprotein cholesterol $\left(\mathrm{mmol} \mathrm{L}^{-1}\right)$ & $2.74 \pm 0.88$ & $2.84 \pm 0.85$ & 0.077 \\
\hline High-density lipoprotein cholesterol (HDL-C, $\left.\mathrm{mmol} \mathrm{L}^{-1}\right)^{*}$ & $0.94 \pm 0.22$ & $1.05 \pm 0.18$ & 0.001 \\
\hline Triglycerides $\left(\mathrm{mmol} \mathrm{L}^{-1}\right)$ & $1.69 \pm 1.14$ & $1.55 \pm 1.30$ & 0.072 \\
\hline TC to HDL-C ratio ${ }^{\dagger}$ & $4.99 \pm 1.59$ & $4.60 \pm 1.51$ & 0.001 \\
\hline Glucose $\left(\mathrm{mmol} \mathrm{L}^{-1}\right)$ & $5.05 \pm 1.38$ & $4.99 \pm 1.55$ & 0.350 \\
\hline Cigarette smokers $(\%)^{\dagger}$ & 19.5 & 2.5 & 0.001 \\
\hline Mean number of cigarettes per day (smokers only) & 8.6 & 7.1 & 0.377 \\
\hline
\end{tabular}

*Significantly higher in women than in men, Chi-square test, p-value shown in last column.

'Significantly higher in men than in women, Chi-square test, p-value shown in last column. 
lected in tubes coated with EDTA and serum in tubes without EDTA. After centrifugation for $10 \mathrm{~min}$ at $3000 \mathrm{rpm}$ the serum was separated and stored at $-70{ }^{\circ} \mathrm{C}$ in $1.5 \mathrm{~mL}$ aliquots. Glucose and lipids were measured immediately from fresh sera. Serum glucose, total cholesterol, HDL-C and triglyceride levels were measured as described by Azizi et $a l .$, (2003). The HDL-C levels were measured after precipitation of lipoproteins containing apolipoprotein B (the primary apolipoprotein of low density lipoproteins (LDL) or 'bad' cholesterol responsible for carrying cholesterol to the tissues), with dextran-magnesium sulfate (Warnick et al., 1982) and LDL-C concentrations in samples with serum triglyceride levels $<10.36 \mathrm{mmol} \mathrm{L}^{-1}$ were calculated using Friedewald's equation (Friedewald et al., 1972). Coefficients of variation (CV) for total cholesterol, HDL-C and triglyceride measurements were below 5\%. The HDL-C distribution in this population was normal, with $41 \%$ of participants having a HDL-C level of $0.90 \mathrm{mmol} \mathrm{L}^{-1}$

We analyzed all 1021 individuals for the TaqI B2/B1 polymorphism in interon 1 of the CETP gene promoter. Buffy coats were separated from the coagulated blood samples and stored at $-70{ }^{\circ} \mathrm{C}$ until processing when genomic DNA was extracted by the salting out method (Truett et al., 2000). The polymerase chain reaction (PCR) was used to amplify a $535 \mathrm{bp}$ fragment of intron 1 of the CETP gene using the 5'-CAC TAG CCC AGA GAG AGG AGT GCC-3' (forward) and 5'-CTG AGC CCA GCC GCA CAC TAAC-3' (reverse) primers (Fermentase Co, Germany). Each amplification was performed using $100 \mathrm{ng}$ of total genomic DNA in a final volume of $25 \mu \mathrm{L}$ containing $40 \mathrm{pmol}$ of each oligonucleotide, $0.2 \mathrm{mmol} \mathrm{L}^{-1}$ of each dNTP, $1.5 \mathrm{mmol} \mathrm{L}^{-1} \mathrm{MgCl}_{2}, 10 \mathrm{mmol} \mathrm{L}^{-1}$ Tris (pH 8.4) and 0.25 units of Taq polymerase (Fermentase Co. Canada). Hybridization was carried out in a DNA Thermal cycler (Hybaid co. England) in which the DNA templates were denatured at $95{ }^{\circ} \mathrm{C}$ for $3 \mathrm{~min}$, amplification consisting of 30 cycles of $95^{\circ} \mathrm{C}$ for $30 \mathrm{~s}, 60{ }^{\circ} \mathrm{C}$ for $30 \mathrm{~s}$ and $72{ }^{\circ} \mathrm{C}$ for $45 \mathrm{~s}$, with a final extension at $72{ }^{\circ} \mathrm{C}$ for $5 \mathrm{~min}$ (Ordovass et al., $2000)$. The PCR products were subjected to restriction enzyme analysis by digestion at $65^{\circ} \mathrm{C}$ for $2 \mathrm{~h}$ with 2 units of TaqI restriction endonuclease in each $10 \mu \mathrm{L}$ of PCR sample in the buffer recommended by the manufacturer of the endonuclease (Fermentase Co. Canada) and the fragments separated by electrophoresis on a $1.5 \%(\mathrm{w} / \mathrm{v})$ agarose gel. After electrophoresis, the gel was treated with ethidium bromide for $10 \mathrm{~min}$, and the DNA fragments visualized by illumination with ultraviolet light. The resulting fragments were 174 and $361 \mathrm{bp}$ for the B1 allele and $535 \mathrm{bp}$ for the uncut B2 allele.

\section{The $\mathrm{n}=335$ population subset}

From the 1021 individuals tested for HDL-C and LDL-C levels and the TaqI polymorphisms we selected three population subsets (total number of individuals $(n=335)$ based on HDL-C levels: the low HDL-C subset $(\mathrm{n}=104,29 \mathrm{~F}+75 \mathrm{M}$, aged $28 \mathrm{y}$ to $44 \mathrm{y})$ with HDL-C levels not exceeding $0.72 \mathrm{mmol} \mathrm{L}^{-1}$ (10th percentile); the medium HDL-C subset ( $\mathrm{n}=127,67 \mathrm{~F}+60 \mathrm{M}$, aged $28 \mathrm{y}$ to $37 \mathrm{y})$ with HDL-C of from $0.96 \mathrm{mmol} \mathrm{L}^{-1}$ (45th percentile) to 1.01 mmol L ${ }^{-1}$ (55th percentile); and the high HDL-C subset ( $\mathrm{n}=104,79 \mathrm{~F}+25 \mathrm{M}$, aged $32 \mathrm{y}$ to $41 \mathrm{y})$ with HDL-C levels of $1.29 \mathrm{mmol} \mathrm{L}^{-1}$ (90th percentile).

We analyzed the DNA of the all 335 individuals for the CETP gene A-629C polymorphism using the PCR reaction and the 5'-TTC TTG GCC CCA GCT GTA GG-3' (sense) and 5'-GAA ACA GTC CTC TAT GTA GAC TTT CCT TGA TAT GCA TAA AAT ACC ACT GG-3' (antisense) primers (Fermentase Co, Germany). The PCR was performed in a final volume of $25 \mu \mathrm{L}$ containing $100 \mathrm{ng}$ DNA, $2.5 \mu \mathrm{mol} / \mathrm{L}$ of each primer, $0.4 \mathrm{mmol} \mathrm{L}^{-1}$ of each dNTP, 0.5 units of Taq polymerase (Fermentas Co. Canada) and $10 \%$ of reaction buffer. Amplification conditions were denaturation for $5 \mathrm{~min}$ at $94{ }^{\circ} \mathrm{C}$, followed by 30 cycles of denaturation for $1 \mathrm{~min}$ at $94^{\circ} \mathrm{C}$, annealing for $1 \mathrm{~min}$ at $62^{\circ} \mathrm{C}$ and extension for $30 \mathrm{~s}$ at $72^{\circ} \mathrm{C}$. The final product was $232 \mathrm{bp}$ long. After restriction with the Van91I restriction enzyme and analysis on $4 \%(\mathrm{w} / \mathrm{v})$ agarose gel the resulting fragments were 175 and $47 \mathrm{bp}$ for the A allele and $232 \mathrm{bp}$ for the uncut $\mathrm{C}$ allele.

\section{The $\mathrm{n}=103$ CETP activity subgroup}

From the $\mathrm{n}=335$ population we selected a subgroup of $\mathrm{n}=103$ individuals ( $56 \mathrm{~F}+47 \mathrm{M}$, aged $4 \mathrm{y}$ to $76 \mathrm{y})$ each of which was homozygous for at least one of the screened alleles and measured their expressed serum CETP activity using a fluorometric kit (BioVision co. USA). We adopted this methodological strategy because of financial constraints.

\section{Statistical analysis}

To compare the men and women who participated in the study, we used the chi-square $\left(\mathrm{P}^{2}\right)$ test for categorical data and the 2-sample Student t-test for continuous variables. Allele frequencies were determined by testing for Hardy-Weinberg equilibrium of the CETP gene variants and the linkage disequilibrium was calculated using the Arlequin http://gb.unige.ch/arlequin/ program to form six groups of genotypes and means, which were compared using analysis of variance (ANOVA), and a multiple comparison Tukey test. The HDL-C level and CETP activity in the different genotypes were compared using the 2-sample t-test.

A sensitivity analysis was carried out to estimate the validity and precision of the regression coefficients for the CETP genotype variables when additional independent terms were included in the model. Regression coefficient and $95 \%$ CI for the B1B2 and B2B2 genotypes compared with the B1B1 genotype were calculated by fitting several linear regression models with dummy variables for categorical and interaction terms as follows: model 1, TaqI ge- 
notype (B1B2 and B2B2 versus B1B1); model 2, model $1+$ sex; model 3, model $2+$ BMI; model 4, model 3+ tobacco smoking (non-smokers and smokers); and model 5, model $4+-629 \mathrm{~A} / \mathrm{C}$ genotypes (AA, AC and CC). In all cases, the first category was used as the reference category. Regression diagnostics were used to check the assumption and to assess the accuracy of computations.

\section{Results}

A summary of the demographic and biochemical characteristics the 1021 individuals selected from the TLGS is given in Table 1. Age, diastolic blood pressure, serum LDL-C, triglyceride and glucose levels were not significantly different between men and women. Systolic blood pressure and TC/HDL-C ratio was significantly higher in men than in women, but BMI and HDL-C were significantly higher in the women. There were significantly $(\mathrm{p}=0.001)$ more male smokers $(19.2 \%)$ than female smokers $(2.5 \%)$ but no significant difference in between men and women smokers regarding the number of cigarettes smoked per day.

A summary of the patient clinical, and lifestyle data and the results for the TaqI and -629A/C CETP gene polymorphisms are presented in Table 2 for the $n=335$ population subset. The CETP gene TaqI B1B1 polymorphism was present at a significantly higher $(\mathrm{p}<0.001)$ frequency $(44.2 \%)$ in the low HDL-C group than in the high HDL-C group $(20.2 \%)$, whereas the frequency of the B2B2 genotype was significantly lower $(\mathrm{p}<0.001)$ in the low HDL-C group $(3.8 \%)$ than in the high HDL-C group (18.3\%). Furthermore, the frequency of the B2 allele was significantly higher $(\mathrm{p}<0.001)$ in the high HDL-C group than in the medium and low HDL-C groups. Similar results occurred for the $-629 \mathrm{~A} / \mathrm{C}$ CETP genotype, the A allele of which was present at a significantly higher $(p<0.001)$ frequency in the high HDL-C group than in the other groups. For the CETP gene $-629 \mathrm{~A} / \mathrm{C}$ genotype the BMI was significantly higher $(\mathrm{p}<0.001)$ in the low HDL-C group than in the high HDL-C group, with triglyceride concentrations being sig-

Table 2 - The $\mathrm{n}=335$ population subset clinical and lifestyle parameters and cholesterol ester transfer protein (CETP) genotypes. Values are, as appropriate, means \pm standard deviation or percentages for the total sub-set (males plus females).

\begin{tabular}{|c|c|c|c|}
\hline \multirow[b]{2}{*}{ Parameters } & \multicolumn{3}{|c|}{ High-density lipoprotein cholesterol (HDL-C) percentiles } \\
\hline & $\begin{array}{c}10^{\text {th }} \text { percentile } \\
\left(0.72 \mathrm{mmol} \mathrm{L}^{-1}\right) \mathrm{n}=104\end{array}$ & $\begin{array}{c}45^{\text {th }} \text { to } 55^{\text {th }} \text { percentile } \\
\left(0.96 \text { to } 1.01 \mathrm{mmol} \mathrm{L}^{-1}\right) \mathrm{n}=127\end{array}$ & $\begin{array}{c}90^{\text {th }} \text { percentile } \\
\left(1.29 \mathrm{mmol} \mathrm{L}^{-1}\right) \mathrm{n}=104\end{array}$ \\
\hline \multicolumn{4}{|l|}{ Clinical and lifestyle parameters } \\
\hline Age (years) & $38 \pm 17$ & $32 \pm 17$ & $35 \pm 22$ \\
\hline Body mass index $\left(\mathrm{kg} \mathrm{m}^{-2}\right)$ & $26.8 \pm 4.5^{*^{\dagger}}$ & $25.0 \pm 5.4$ & $23.4 \pm 5.6$ \\
\hline Systolic blood pressure $(\mathrm{mm} \mathrm{Hg})$ & $115 \pm 19^{\dagger}$ & $111 \pm 19$ & $107 \pm 15$ \\
\hline Diastolic blood pressure (mm Hg) & $73 \pm 10^{\dagger}$ & $72 \pm 10$ & $70 \pm 9.5$ \\
\hline Total cholesterol (TC, $\left.\mathrm{mmol} \mathrm{L}^{-1}\right)$ & $4.40 \pm 0.80$ & $4.24 \pm 0.80^{*}$ & $4.53 \pm 0.82$ \\
\hline $\begin{array}{l}\text { Low-density lipoprotein cholesterol } \\
\left(\text { LDL-C, } \mathrm{mmol} \mathrm{L}^{-1}\right)\end{array}$ & $2.77 \pm 0.75$ & $2.64 \pm 0.69$ & $2.56 \pm 0.77$ \\
\hline Triglycerides $\left(\mathrm{mmol} \mathrm{L}^{-1}\right)$ & $2.1 \pm 0.96^{* \dagger}$ & $1.35 \pm 0.73^{\ddagger}$ & $1.09 \pm 0.53$ \\
\hline TC:HDL-C ratio & $6.66 \pm 1.35^{* \dagger}$ & $4.34 \pm 0.85^{\ddagger}$ & $3.13 \pm 0.69$ \\
\hline Smokers $(\%)$ & $20.4^{\dagger}$ & 6.0 & 1.9 \\
\hline Cigarettes per day & 7 & 5 & 12 \\
\hline \multicolumn{4}{|l|}{ TaqI-CETP genotype } \\
\hline $\mathrm{B} 1 \mathrm{~B} 1 \%$ & 44.2 & 34.9 & 20.2 \\
\hline $\mathrm{B} 1 \mathrm{~B} 2 \%$ & 51.9 & 59.5 & 61.5 \\
\hline $\mathrm{B} 2 \mathrm{~B} 2 \%$ & 3.8 & 5.6 & 18.3 \\
\hline B2 allele frequency & 0.221 & 0.353 & 0.490 \\
\hline \multicolumn{4}{|l|}{-629A/C CETP genotype } \\
\hline $\mathrm{CC} \%$ & 40.4 & 31 & 20.2 \\
\hline $\mathrm{AC} \%$ & 40.4 & 52.4 & 46.2 \\
\hline $\mathrm{AA} \%$ & 19.2 & 16.7 & 33.7 \\
\hline A allele frequency & 0.394 & 0.428 & 0.567 \\
\hline
\end{tabular}

*HDL-C $10^{\text {th }}$ percentile $v$ s. HDL-C $45^{\text {th }}$ to $55^{\text {th }}$ percentile, significant at $\mathrm{p}<0.001$ by the Tukey test.

${ }^{t}$ HDL-C $10^{\text {th }}$ percentile $v s$. HDL-C $90^{\text {th }}$ percentile, significant at $\mathrm{p}<0.001$ by the Tukey test.

${ }^{7}$ HDL-C $45^{\text {th }}$ to $55^{\text {th }}$ percentile $v s$. HDL-C $90^{\text {th }}$ percentile, significant at $\mathrm{p}<0.001$ by the Tukey test. 
nificantly higher $(\mathrm{p}<0.001)$ in the low HDL-C group than in the other two groups. The percentage of smokers in the low HDL-C group (20.4\%) was significantly higher $(\mathrm{p}<0.001)$ than in the high HDL-C group $(1.9 \%)$.

The demographic and biochemical characteristics of individuals in the three HDL-C groups constituting the $\mathrm{n}=335$ population subset, grouped according to the six possible genetic types, are shown in Table 3. The data shows that individuals homozygous for the $\mathrm{B} 2$ or A alleles had higher HDL-C levels than individuals who were heterozygous for these alleles or who were homozygous for the $\mathrm{B} 1$ or $\mathrm{C}$ alleles, with the same relationship also being found between the TC/HDL-C ratio and $\mathrm{B} 2$ and $\mathrm{A}$ alleles. However, after adjusting for the effect of age and BMI within groups, no statistically significant change was observed. Also, there was no interaction between genotypes and smoking in regard to lipid variables.

The observed genotype frequencies were in the HardyWeinberg equilibrium (Table 4) and both the $629 \mathrm{~A} / \mathrm{C}$ and TaqI polymorphisms were in tight, but not complete, linkage disequilibrium $\left(\mathrm{D}=0.0965 ; \mathrm{D}^{\prime}=0.4695\right)$. The majority of individuals with the B2B2 genotype were carriers of the AA genotype.

We carried out sensitivity linear regression analysis to investigate the consistency of the association between the CETP TaqI genotype and HDL-C levels, Figure 1 showing the regression coefficients and $95 \%$ confidence intervals for the B1B2 and B2B2 genotypes compared with the B1B1 genotypes when each indicated variable was included in linear regression models 1 to 6 . In model 1 the only variables included were dummies for the Taq I genotype, this genetic factor accounting for $5.8 \%$ of the HDL-C variability $(\mathrm{p}<0.001)$. In model 2 , after controlling for the effect of the sex the initial regression coefficients for the B1B2 genotype were HDL-C $=0.089 \mathrm{mmol} \mathrm{L}^{-1}(95 \% \mathrm{CI}$ of $0.016 \mathrm{mmol} \mathrm{L}^{-1}$ to $0.1615 \mathrm{mmol} \mathrm{L}^{-1}$ ), significant at $\mathrm{p}=0.016$ as compared to $\mathrm{B} 1 \mathrm{~B} 1$, while for the $\mathrm{B} 2 \mathrm{~B} 2$ genotype HDL-C $=0.246 \mathrm{mmol} \mathrm{L}^{-1}\left(95 \% \mathrm{CI} 0.123 \mathrm{mmol} \mathrm{L}^{-1}\right.$ to $\left.0.369 \mathrm{mmol} \mathrm{L}^{-1}\right)$, significant at $\mathrm{p}<0.001$ as compared to B1B1. When other variables (BMI, smoking) were progressively added to the core model the initially estimated regression coefficient values varied only slightly, indicating revealing an independent association between the TaqI polymorphism and HDL-C levels with a strong consistency whether or not an additional environmental component was considered. Model 6, the final model, explained $40.8 \%$ of the variability of HDL-C in the $n=335$ population subset and showed the $\mathrm{B} 2$ allele effect in the presence of the A allele in the $-629 \mathrm{~A} / \mathrm{C}$ polymorphism by the increasing HDL$\mathrm{C}$ level (significant at $\mathrm{p} \leq 0.05$ ).

To examine the effect of the presence of the $\mathrm{B} 2$ and $\mathrm{A}$ alleles on HDL-C concentration and CETP activity we measured the phenotypic CETP activity of the 103 homozygous individuals in the $\mathrm{n}=103$ CETP activity subgroup (Table 4) TaqI polymorphism B1 allele homozygotes

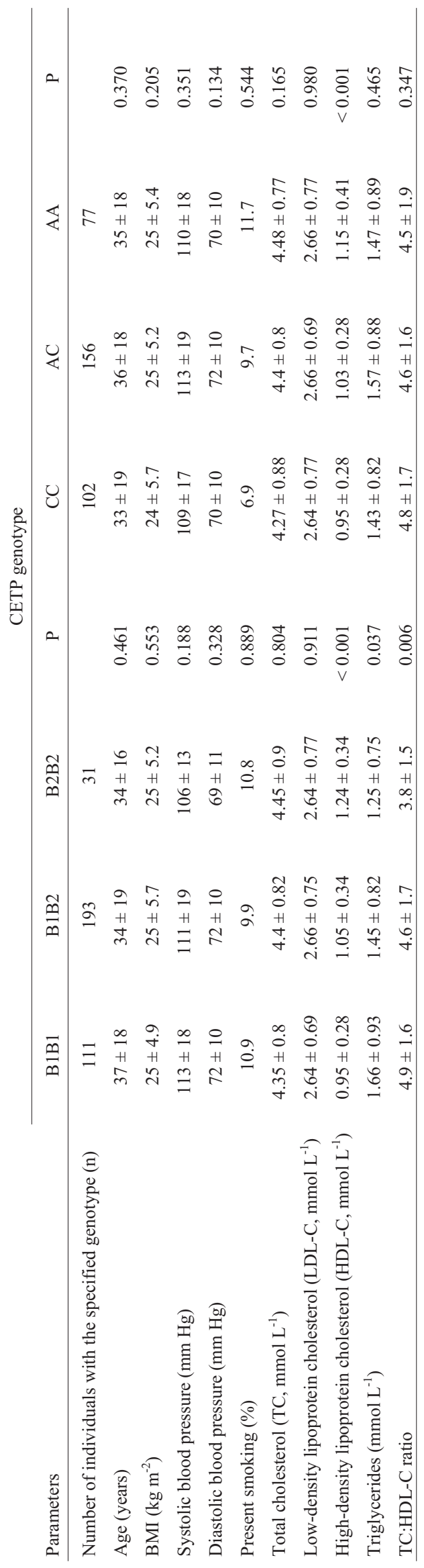


Table 4 - The cholesterol ester transfer protein (CETP) TaqI and A-629C polymorphism distribution in the $\mathrm{n}=335$ subset plus the high-density lipoprotein cholesterol (HDL-C) level and expressed CETP activity in the $\mathrm{n}=103$ subpopulation according to the type of TaqI B1/B2 and $-629 \mathrm{~A} / \mathrm{C}$ restriction fragment length polymorphism (RFLP).

\begin{tabular}{|c|c|c|c|c|c|c|}
\hline \multicolumn{4}{|c|}{$\begin{array}{c}\text { Frequency of TaqI A-629C polymorphisms in the } \mathrm{n}=335 \\
\text { population subset }\end{array}$} & \multicolumn{3}{|c|}{$\begin{array}{l}\text { CETP activity and HDL-C level in the } \mathrm{n}=103 \text { subpopulation } \\
\text { according to TaqI and }-629 \mathrm{~A} / \mathrm{C} \text { genotype }\end{array}$} \\
\hline \multirow[t]{2}{*}{$\begin{array}{c}\text { TaqI RFLP } \\
\text { polymorphism }\end{array}$} & \multicolumn{3}{|c|}{$\begin{array}{l}\text { Number of individuals with different A-629C } \\
\text { genotypes, \% in parentheses }\end{array}$} & $\begin{array}{l}\text { Genotype and RFLP } \\
\text { polymorphism }\end{array}$ & $\begin{array}{l}\text { HDL-C } \\
\left(\mathrm{mmol} \mathrm{L}^{-1}\right)\end{array}$ & $\begin{array}{l}\text { CETP activity } \\
\left(\text { pmol L }^{-1}\right)\end{array}$ \\
\hline & A-629A & A-629C & C-629C & & & \\
\hline B1B1 & $13(11.7)$ & $41(36.9)$ & $57(51.4)$ & TaqI, $\mathrm{n}=103$ & & \\
\hline B1B2 & $49(25.4)$ & $107(55.4)$ & $37(19.2)$ & $\mathrm{B} 1 \mathrm{~B} 1, \mathrm{n}=72$ & $0.98 \pm 0.13 *$ & $67.8 \pm 8.9^{\ddagger}$ \\
\hline B2B2 & $15(48.4)$ & $8(25.8)$ & $8(25.8)$ & $\mathrm{B} 2 \mathrm{~B} 2 / \mathrm{B} 1 \mathrm{~B} 2 . \mathrm{n}=31$ & $1.36 \pm 0.36^{*}$ & $62.6 \pm 9.6^{\ddagger}$ \\
\hline \multirow[t]{4}{*}{ Total, $\mathrm{n}=335$} & 77 (100) & $156(100)$ & $102(100)$ & & & \\
\hline & & & & $-629 \mathrm{~A} / \mathrm{C}, \mathrm{n}=103$ & & \\
\hline & & & & $\mathrm{AA} / \mathrm{AC}, \mathrm{n}=41$ & $1.29 \pm 0.40^{\dagger}$ & $62.7 \pm 9.7^{\S}$ \\
\hline & & & & $\mathrm{CC}(\mathrm{n}=62)$ & $0.97 \pm 0.32^{\dagger}$ & $68.6 \pm 8.4^{\S}$ \\
\hline
\end{tabular}

*Significantly different by the Chi-square test at $\mathrm{p}<0.001$; ${ }^{\dagger}$ Significantly different by the Chi-square test at $\mathrm{p}<0.001$; ${ }^{*}$ Significantly different by the Chi-square test at $\mathrm{p}=0.01$; and ${ }^{\S}$ Significantly different by the Chi-square test at $\mathrm{p}=0.002$.

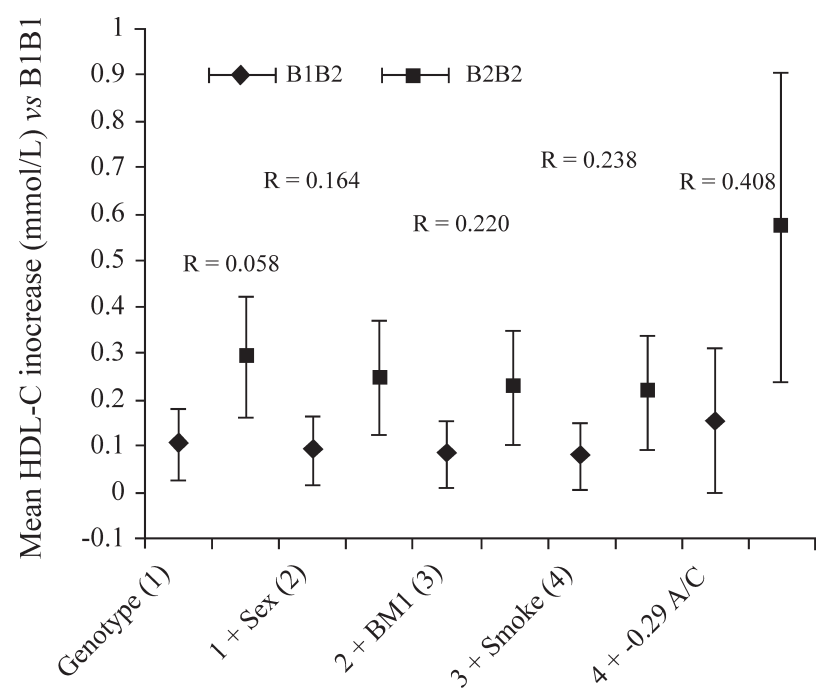

Figure 1 - Sensitivity analysis. Regression coefficient and 95\% confidence intervals (CI) shown for the CETP gene TaqI B1B2 and B2B2 alleles compared with the B1B1 allele when each indicated variable was progressively included into the linear regression modes. Models are as follows: model 1, TaqI genotype; model $2=\operatorname{model} 1+$ sex; model $3=$ model $2+$ BMI; model $4=$ model $3+$ tobacco smoking; and model $5=$ model 4+ $-629 \mathrm{~A} / \mathrm{C}$ genotypes. $\mathrm{R}^{2}$ values are included to show the variability accounted for in each regression model. *The $\mathrm{p}$ values were less than 0.05 except for the BMI and AC alleles.

$(\mathrm{n}=72)$ had a significantly higher $(\mathrm{p}<0.01)$ CETP activity $\left(67.8 \mathrm{pmol} \mathrm{L}^{-1} \pm 8.9 \mathrm{pmol} \mathrm{L}^{-1}\right)$ and lower HDL-C value (HDL-C $=0.98 \mathrm{mmol} \mathrm{L}^{-1} \pm 0.13 \mathrm{mmol} \mathrm{L}^{-1}$ ) than B2 allele homozygotes or B1B2 heterozygotes $(\mathrm{n}=31$; CETP activity $=62.6 \mathrm{pmol} \mathrm{L}^{-1} \pm 9.6 \mathrm{pmol} \mathrm{L}^{-1}$, HDL-C $=1.36 \mathrm{mmol} \mathrm{L}^{-1}$ $\left.\pm 0.36 \mathrm{mmol} \mathrm{L}^{-1}\right)$. Similar observations were found with stratification for the A-629C polymorphism, with CC homozygotes $(\mathrm{n}=62)$ having a significantly higher $(\mathrm{p}<0.002)$ CETP activity $\left(68.6 \mathrm{pmol} \mathrm{L}^{-1} \pm 8.4 \mathrm{pmol} \mathrm{L} \mathrm{L}^{-1}\right)$ and lower HDL-C value (HDL-C $=0.97 \mathrm{mmol} \mathrm{L}^{-1} \pm 0.32$ mmol L ${ }^{-1}$ ) compared with A allele homozygotes or $\mathrm{A} / \mathrm{C}$ heterozygotes $\left(n=41\right.$; CETP activity $=62.7 \pm 9.7 \mathrm{pmol} \mathrm{L}^{-1}$, $\left.\mathrm{HDL}-\mathrm{C}=1.29 \mathrm{mmol} \mathrm{L}^{-1} \pm 0.4 \mathrm{mmol} \mathrm{L}^{-1}\right)$.

\section{Discussion}

We investigated whether the common CETP gene TaqI and A-629C polymorphisms were associated with HDL-C levels in a sample population from the Tehran. The allele frequency was 0.622 for the TaqI B1 polymorphism and 0.538 for the $\mathrm{C}$ allele of the A-629C polymorphism, with the percentage of $\mathrm{B} 2$ and $\mathrm{A}$ allele homozygotes being lower than heterozygotes. There was also a relationship between HDL-C levels and the TaqI and A-629C polymorphisms, both of which were in linkage disequilibrium. In addition, we found a negative relationship between CETP activity and HDL-C levels.

Cardiovascular diseases are a leading cause of death in most industrialized countries, with both genetic and environmental factors having been shown to play an important role in their etiology. Low plasma HDL-C levels are associated with an increase in the risk of coronary artery disease (Gordon et al., 1977) and genetic factors are known to play an important role in determining inter-individual variation in plasma HDL-C levels. In the TLGS report, $73 \%$ of those surveyed had low HDL-C values (Azizi et al., 2002), a higher percentage than has been reported for populations from the United States (Heiss et al., 1980), Turkey (Fumeron et al., 1995), Canada (Hsu et al., 2002) and the United Kingdom (Tai et al., 2003). This could be attributed to industrialization of the country, modification of life style, unhealthy diet, decreased physical activity, and increased prevalence of hypertriglyceridemia, obesity and smoking (Azizi et al., 2003).

We found an association between the CETP gene TaqI and $-629 \mathrm{~A} / \mathrm{C}$ polymorphisms and HDL-C levels but 
there were no statistically significant differences in respect of other lipid levels across TaqI and -629A/C genotypes after controlling for familial relations, age, BMI and smoking. Several previous studies have shown associations between the CETP gene TaqI interon 1 polymorphism and HDL-C, LDL-C and triglyceride levels (Kondo et al., 1989; Kuivenhoven et al., 1998). The mechanism by which the CETP gene TaqI polymorphism may affect CETP activity or HDL-C levels are unknown, although, being located in an intron, it is unlikely that this polymorphism represents a functional mutation. Given the reported associations of the TaqI B2 allele with increased CETP mass and/or activity, the most plausible explanation is that this polymorphism is in linkage disequilibrium with a still unknown functional mutation in the regulatory region of the CETP gene. In all previous studies, the TaqI and the A-629C polymorphisms were in strong, though not complete, linkage disequilibrium, supporting the hypothesis that the A-629C variant, located in the promoter region of the CETP gene promoter, might explain the observed relationships. We also found this association in our Iranian population. The role of CETP in atherogenesis is still under debate, but this enzyme may have a proatherogenic role in view of the fact that it mediates redistribution of plasma cholesterol from lipoproteins associated with protection against atherosclerosis to proatherogenic apolipoprotein B, the primary apolipoprotein of low density lipoproteins (LDL) or 'bad' cholesterol responsible for carrying cholesterol to the tissues. This proposition is also supported by the fact that animal species that are resistant to diet-induced atherosclerosis have little CETP activity.

Various studies in human populations have analyzed possible interactions between environmental factors and the CETP-TaqI polymorphism and their effects on plasma HDL-C levels, with Kondo et al having shown that the association between the CETP gene and HDL-C levels was present only in nonsmokers. In a Finish study male smokers with the B2 allele tended to have 10\% lower HDL-C levels than male smokers with the B1 allele but this effect was not observed in women smokers, although there was a relationship between the B2 allele and HDL-C levels in women when both smokers and non-smokers were considered. (Kauma et al.1996). In our study, when gene/environment interactions were tested no statistically significant interactions were seen between TaqI genotype and tobacco smoking, although a significant trend was seen in the percentile of smokers in the low to high HDL-C groups. The study of gene/environment interactions can provide an important basis for refining the predictive value of traditional epidemiological risk factors and for targeting intervention and prevention activities for high-risk individuals.

In this study, we compared three carefully selected groups that were fully matched for factors known to influence HDL-C cholesterol levels. Our findings strongly support the hypothesis that the TaqI B1 allele is indeed associated with hypoalpha lipoproteinemia. The frequency of the TaqI B2 allele in our Iranian population was lower than that reported in studies from other countries (Heiss et al., 1980, Fumeron et al.1995, Hsu et al, 2002) and the United Kingdom (Tai et al., 2003) In summary, we have demonstrated that the TaqI and $-629 \mathrm{~A} / \mathrm{C}$ polymorphisms at the CETP gene locus are associated with changes in HDL$\mathrm{C}$ levels, that the frequency of the B2 allele of the TaqI polymorphism is lower in Iran but the frequency of the $-629 \mathrm{~A} / \mathrm{C}$ polymorphism A allele is similar to that of other Caucasian populations.

\section{References}

Agellon LB, Quinet EM, Gillette TG, Drayna DT, Brown ML and Tall AR (1990) Organization of the human cholesteryl ester transfer protein gene. Biochem 29:1372-1376.

Assmann G, Schulte H, Oberwitter W and Hause WH (1986) New aspects in the prediction of coronary artery disease: The prospective cardiovascular munster study. In: Fidge $\mathrm{NH}$ and Nestel PJ (eds) Atherosclerosis VII. Elsevier Science Publishers, Amsterdam, pp 19-24.

Azizi F, Rahmani M and Majid M (2000) Tehran lipid and glucose study (TLGS): Rationale and design. CVD Prevention 3:50-53.

Azizi F, Rahmani M, Ghanbarian A, Emami H, Salehi P, Mirmiran P and Sarbazi N (2003a) A serum lipid level in an Iranian adult's population: Tehran lipid and glucose study. Eur J Epidemiol 18:311-319.

Azizi F, Salehi P, Etemadi A and Zahedi-Asl S (2003b) Prevalence of metabolic syndrome in an urban population: Tehran lipid and glucose study. Diabetes Res Clin Pract 61:29-37.

Brown ML, Inazu A, Hesler CB, Agellon LB, Mann C, Whitlock ME, Marcel YL, Milne RW, Koizumi J, Mabuchi H, et al. (1989) Molecular basis of lipid transfer protein deficiency in a family with increased high-density lipoproteins. Nature 342:448-451.

Bruce C and Tall AR (1995) Cholesteryl ester transfer proteins, reverses cholesterol transport, and arteriosclerosis. Curr Opin Lipidol 6:306-311.

Corbex M, Poirier O, Fumeron F, Betoulle D, Evans A, Ruidavets JB, Arveiler D, LucG, Tiret L and Cambien F (2000) Extensive association analysis between the CETP gene phenotypes reveals several putative functional polymorphisms and gene-environment interaction. Genet Epidemiol 19:64-80.

Dachet C, Poirier O, Cambien F, Chapman J and Rouis M (2000) New functional promoter polymorphism, CETP/-629, in cholesteryl ester transfer protein (CETP) gene related to CETP mass and high density lipoprotein cholesterol levels: Role of Sp1/Sp3 in transcriptional regulation. Arterioscler Thromb Vasc Biol 20:507-515.

Drayna D and Lawn R (1987) Multiple RFLPs at the human cholesteryl ester transfer protein (CETP) locus. Nucleic Acids Res 15:4698.

Fielding CJ and Fielding PE (1995) Molecular physiology of reverse cholesterol transport. J Lipid Res 36:211-228.

Francene V, Ronald P, Jane-dirk B, Tjeerd P and Arie T (2003) Common cholestryl ester transfer protein gene polymorphisms and the effect of atorvastatin therapy type 2 diabetes. Diabets care 26:1216-1223. 
Freeman DJ, Griffin BA, Holmes AP, Lindsay GM, Gaffney D, Packard CJ and Shepherd J (1994) Regulation of plasma HDL-C and subfraction distribution by genetic and environmental factors: Associations between the TaqI B RFLP in the CETP gene and smoking and obesity. Arterioscler Thromb 14:336-344.

Friedewald WT, Levy RI and Fredrickson DS (1972) Estimation of the concentration of low-density lipoprotein cholesterol in plasma without use of preparative ultracentrifuge. Clin Chem 18:499-502.

Fumeron F, Betoulle D, Luc G, Behague I, Ricard S, Poirier O, Jemaa R, Evans A, Arveiler D, Marques-Vidal P, et al. (1995) Related articles, alcohol intake modulates the effect of a polymorphism of the cholesteryl ester transfer protein gene on plasma high density lipoprotein and the risk of myocardial infarction. J Clin Invest 96:1664-1671.

Gordon T, Castelli WP, Hjortland MC, Kannel WB and Dawber TR (1977) High-density lipoprotein as a protective factor against coronary heart disease: The Framingham heart study. Am J Med 62:707-714.

Heiss G, Tamir I, Davis CE, Tyroler HA, Rifkand BM, Schonfeld G, Jacobs D and Frantz Jr ID (1980) Related articles, lipoprotein-cholesterol distributions in selected North American populations: The lipid research clinics program prevalence study. Circulation 61:302-315.

Hirano K, Yamashita S, Kuga Y, Sakai N, Nozaki S, Kihara S, Arai T, Yanagi T, Takami S, Menju M, et al. (1995) Atherosclerotic disease in marked hyperalphalipoproteinemia. Arterioscler Thromb Vasc Biol 15:1849-1856.

Hsu LA, Ko YL, Hsu KH, Ko YH and Lee YS (2002) Genetic variations in the cholesteryl ester transfer protein gene and high density lipoprotein cholesterol levels in Taiwanese Chinese. Hum Genet 110:57-63.

Inazu A, Brown ML, Hesler CB, Agellon LB, Koizumi J, Takata K, Maruhama Y, Mabuchi H and Tall AR (1990) Increased high-density lipoprotein levels caused by a common cholesteryl-ester transfer protein gene mutation. N Engl J Med 323:1234-1238.

Inazu A, Brown ML, Hesler CB, Agellon LB, Koizumi J, Takata K, Maruhama Y, Mabuchi H and Tall AR (1990) Increased high-density lipoprotein levels caused by a common cholesteryl-ester transfer protein gene mutation. N Engl J Med 323:1234-1238.

Kauma H, Savolainen MJ, Heikkila R, Rantala AO, Lilja M, Reunanen A and Kesaniemi YA (1996) Related articles, sex difference in the regulation of plasma high density lipoprotein cholesterol by genetic and environmental factors Hum Genet 97:156-162.
Kondo I, Berg K, Drayna DT and Lawn RM (1989) DNA polymorphism at the locus for human cholesteryl ester transfer protein (CETP) is associated with high-density lipoprotein cholesterol and apolipoprotein levels. Clin Genet 35:49-56.

Kuivenhoven JA, Jukema JW, Zwinderman AH, de Knijff P, McPherson R, Bruschke AV, Lie KI and Kastelein JJ (1998) The role of a common variant of the cholesteryl ester transfer protein gene in the progression of coronary arteriosclerosis: The regression growth evaluation statin study group. $\mathrm{N}$ Engl J Med 338:86-93.

Miller NE, Thelle DS, Forde OH and Mjos OD (1997) The Tromso heart study: High-density lipoprotein and coronary heart disease: A prospective case-control study. Lancet 1:965-968.

Mitchell RJ, Earl L, Williams J, Bisucci T and Gasiamis H (1994) Polymorphisms of the gene coding for the cholesteryl ester transfer protein and plasma lipid levels in Italian and Greek migrants to Australia. Hum Biol 66:13-25.

Ordovas JM, Cupples A, Corella D, Otvos JD and Osgood D (2000) Association of cholesteryl ester transfer protein-TaqI polymorphism with variation in lipoprotein sub classes and coronary heart disease risk. Arterioscler Thromb Vasc Biol 20:1323-1329.

Tall AR (1993) Plasma cholesteryl ester transfer protein. J Lipid Res 34:1255-1274.

Tenkanen H, Koskinen P, Kontula K, Aalto-Setala K, Manttari M, Manninen V, Runeberg SL, Taskinen MR and Ehnholm C (1991) Polymorphisms of the gene encoding cholesterol ester transfer protein and serum lipoprotein levels in subjects with and without coronary heart disease. Hum Genet 87:574-578.

Truett GE, Walker JA, Ttuett AA, Mynatt RL, Heeger P and Warman M (2000) Preparation of PCR-quality DNA with hot sodium hydroxide and Tris (HOTSHOT). Biotechniques 29:52-54.

Warnick GR, Benderson J and Albers JJ (1982) Dextran sulfate-Mg21 precipitation procedure for quantitation of highdensity-lipoprotein cholesterol. Clin Chem 28:1379-1388.

Yen FT, Deckelbaum RJ, Mann CJ, Marcel YL, Milne RW and Tall AR (1989) Inhibition of cholesteryl ester transfer protein activity by monoclonal antibody: Effects on cholesteryl ester formation and neutral lipid mass transfer in human plasma. J Clin Invest 83:2018-2024.

\section{Internet Resource}

Tehran Lipid and Glucose Study (TLGS) http://www.erc.ac.ir/ $\operatorname{tlgs} /$.

Associate Editor: Peter L. Pearson 